\title{
Production of Newcastle Disease Virus by Vero Cells Grown on Cytodex 1 Microcarriers in a 2-Litre Stirred Tank Bioreactor
}

\author{
Mohd Azmir Arifin, ${ }^{1}$ Maizirwan Mel, ${ }^{1}$ Mohamed Ismail Abdul Karim, ${ }^{1}$ and Aini Ideris ${ }^{2}$ \\ ${ }^{1}$ Department of Biotechnology Engineering, Kulliyah of Engineering, International Islamic University Malaysia, Gombak, P.O. Box 10, \\ 50728 Kuala Lumpur, Malaysia \\ ${ }^{2}$ Faculty of Veterinary Medicine, Putra University Malaysia, Serdang, 43400 Selangor Darul Ehsan, Malaysia
}

Correspondence should be addressed to Maizirwan Mel, maizirwan@iiu.edu.my

Received 19 January 2010; Revised 29 March 2010; Accepted 31 March 2010

Academic Editor: Fred Kibenge

Copyright ( $) 2010$ Mohd Azmir Arifin et al. This is an open access article distributed under the Creative Commons Attribution License, which permits unrestricted use, distribution, and reproduction in any medium, provided the original work is properly cited.

The aim of this study is to prepare a model for the production of Newcastle disease virus (NDV) lentogenic F strain using cell culture in bioreactor for live attenuated vaccine preparation. In this study, firstly we investigated the growth of Vero cells in several culture media. The maximum cell number was yielded by culture of Vero cells in Dulbecco's Modified Eagle Medium (DMEM) which was $1.93 \times 10^{6} \mathrm{cells} / \mathrm{ml}$. Secondly Vero cells were grown in two-litre stirred tank bioreactor by using several commercial microcarriers. We achieved the maximum cell concentration about $7.95 \times 10^{5}$ cells $/ \mathrm{ml}$ when using Cytodex 1 . Later we produced Newcastle Disease virus in stirred tank bioreactor based on the design developed using Taguchi L4 method. Results reveal that higher multiplicity of infection (MOI) and size of cell inoculums can yield higher virus titer. Finally, virus samples were purified using high-speed centrifugation based on $3^{* *}(3-1)$ Fractional Factorial Design. Statistical analysis showed that the maximum virus titer can be achieved at virus sample concentration of $58.45 \%(\mathrm{v} / \mathrm{v})$, centrifugation speed of $13729 \mathrm{rpm}$, and centrifugation time of 4 hours. As a conclusion, high yield of virus titer could be achieved through optimization of cell culture in bioreactor and separation by high-speed centrifugation.

\section{Introduction}

Newcastle disease (ND), caused by Newcastle disease virus (NDV), is reported as the most important viral disease of poultry in the world [1]. ND has been a devastating disease of poultry, and in many countries the disease remains one of the major problems affecting existing or developing poultry industries. The disease can vary from clinically inapparent to highly virulent forms, depending on the virus strain and the host species [2]. NDV belongs to the Avulavirus genus within the family Paramyxoviridae, subfamily Paramyxovirinae, in the order Mononegavirales and is designated avian paramyxovirus-1 (APMV-1). Nine avian paramyxovirus serotypes (APMV-1 to APMV-9), of which APMV-1 is the most economically important, have been identified among these virus types [3]. The enveloped virus has a negative-sense, single-stranded RNA genome which codes for six proteins including a nucleoprotein $(\mathrm{N})$, phosphoprotein $(\mathrm{P})$, matrix $(\mathrm{M})$ protein, fusion $(\mathrm{F})$ protein, hemagglutinin-neuraminidase $(\mathrm{HN})$ protein, and an RNA directed RNA polymerase (L) in the $3^{\prime}$ to $5^{\prime}$ direction [4]. NDV isolates display a spectrum of virulence in chickens, from a fatal to an inapparent infection [3]. Strains of NDV are classified into three major pathotypes, depending on the severity of disease produced in chickens. Lentogenic strains do not usually cause disease in adult chickens and are widely used as live vaccines in poultry industries in the United States and other countries. Viruses of intermediate virulence that cause respiratory disease are termed mesogenic, while virulent viruses that cause high mortality are termed as velogenic [5].

Until now, there is no treatment for the disease [6]. Prevention is to import birds from disease-free flocks only [7] or through vaccination that must continue throughout the life of the bird [6]. Traditionally, ND vaccines have been produced by growing vaccine virus strains in embryonated 
chicken eggs. NDV is harvested from the allantoic fluid and processed to create a vaccine. However, this procedure has the disadvantages of being labour-intensive, time consuming and requires large area for the incubation of eggs. Cell cultures on the other hand are more convenient and less expensive than eggs and also convenient to examine microscopically for evidence of viral proliferation. However the current titers of NDV propagated in cell cultures are usually lower than those obtained in embryonated eggs. Nevertheless, some manufacturers still find it economically feasible to use the more mechanized cell culture methodology for producing inactivated ND vaccines [8]. Mechanism to produce NDV vaccine is keep diagnosed and updated time by time to improve the production.

Cell substrate systems that have been identified to be able to produce NDV are Vero (African Green Monkey), CEF (chicken embryonic fibroblasts), and DF-1 (continuous cell line derived from CEF) $[4,9,10]$. These cells are anchorage dependent where they require surface of a matrix to facilitate cell growth. Microcarrier technology which was introduced by Van Wezel for culturing anchorage-dependent cells in suspension is easily applied in stirred tank bioreactors; it is scalable, and it is able to produce high number of cells per volume ratio [11]. Microcarrier cell culture system offers many advantages over conventional flasks or bottle cultures in growing anchorage-dependent cells and has been used for the industrial manufacture of polio, rubella, rabies, influenza, and foot-and-mouth disease (FMD) vaccines [12$15]$.

This work addresses the production of F strain of NDV in cultured Vero cells. To achieve high virus titer we have determined the most suitable culture media and microcarrier which are able to yield the highest cell number. Later we investigated the effect of different sizes of cell inoculum, serum concentrations during virus growth phase, and multiplicity of infection (MOI) on the virus titer. We have also optimized the operating condition for purifying NDV using high-speed centrifugation method. All these results constitute valuable information on the development of a large-scale microcarrier cell culture process for producing NDV vaccine.

\section{Methodology}

2.1. Cell Line. Vero cells obtained from the Veterinary Research Institute (Ipoh, Malaysia) were used in this study.

2.2. Virus Strain. Lentogenic F strain of NDV adapted to grow in Vero cells and provided by Universiti Putra Malaysia (Selangor, Malaysia) was used throughout the study.

2.3. Culture Media and Chemicals. DMEM, RPMI, MEM, and L-15 media were supplied by Invitrogen (Glasgow, UK). RPMI without phenol red media was supplied by Mediatech (Virginia, USA). Fetal bovine serum (FBS) and antibiotic (Penstrep) were supplied by Invitrogen (Glasgow, UK). Accutase enzyme was provided by Innovative Cell (California, USA). Cytodex 1 and Cytodex 3 microcarriers were obtained from Amersham Biosciences (Uppsala, Sweden). Hillex and Plustic Plus microcarriers were obtained from SoloHill (Michigan, USA). All other chemicals were obtained from Sigma (St. Louis, USA).

2.4. Microcarrier Preparation. Cytodex 1, Cytodex 3, Hillex, and Plustic Plus microcarriers were prepared and sterilized according to manufacturer's instructions. For Cytodex 1 and Cytodex 3, the microcarriers were swollen with $\mathrm{Ca}^{2+}, \mathrm{Mg}^{2+}$ free PBS twice and autoclaved at $115^{\circ} \mathrm{C}$ for 15 minutes while for Hillex and Plustic Plus microcarriers, they were washed with deionized water and autoclaved at $121^{\circ} \mathrm{C}$ for 30 minutes. All microcarriers were washed and incubated with culture media prior to use.

2.5. Growth in Static Culture. Vero cells were grown in serum containing medium as described by Freshney [16]. Static cultures of cells were carried out under these conditions: a seeding density of $1 \times 10^{5} \mathrm{cells} / \mathrm{cm}^{2}$, temperature of $37^{\circ} \mathrm{C}$, and $5 \%$ concentration of $\mathrm{CO}_{2}$.

2.6. Bioreactor Cultures. Cultures were performed in a $1.5 \mathrm{~L}$ bioreactor (Infors HT, Switzerland) with one-litre working volume and equipped with an elephant ear impeller. For starting the microcarrier cultures, the cells were detached from T-flasks using Accutase enzyme and incubated in the reactor in the presence of the microcarriers. The culture was seeded with $5 \times 10^{4}$ cells $/ \mathrm{mL}$ and was continuously agitated at $70 \mathrm{rpm}$. The starting volume was equal to $1 \mathrm{~L}$. During cell culture proliferation phase, the following conditions were applied: $\mathrm{pH}$ set at 7.2 (regulated by injection of $\mathrm{CO}_{2}$ and addition of $1 \mathrm{M} \mathrm{HCL}$ and $1 \mathrm{M} \mathrm{NaOH}$ ), $\mathrm{pO}_{2}$ maintained at $30 \%$ air-saturation by injecting air when required, temperature at $37^{\circ} \mathrm{C}$, and agitation rate at $70 \mathrm{rpm}$.

For NDV production phase, $\mathrm{pH}$ was maintained at 7.4, $\mathrm{pO}_{2}$ at $30 \%$ air-saturation, agitation rate at $100 \mathrm{rpm}$, and temperature at $37^{\circ} \mathrm{C}$. Once cell density reached maximum, cells were washed with PBS. Later cells were infected with NDV according to the designed levels by inoculation of virus in DMEM supplemented with trypsin. After 1 hour of cell infection, more DMEM was added until the working volume reaches one litre and the stirring was restarted. Samples were taken daily to determine the following factor: cell concentration, cell viability, and virus titer. Cell concentration was counted by counting cell released after trypsinization [17].

2.7. Specific Growth Rate and Doubling Time. Calculation of specific growth rate $(\mu)$ using the formula of Scheirer and Merten [18] was used:

$$
\mu x=\left(\frac{\ln X_{n}-\ln X_{n-1}}{t_{n}-t_{n-1}}\right),
$$

where $X$ represents the viable cell density per $\mathrm{mL}$, and $t$ the time points of sampling expressed in hours; $n$ and $n-1$ stand for two succeeding sampling points. 
Doubling time $\left(t_{D}\right)$ is given by the formula:

$$
t_{d}=\left(\frac{\ln 2}{\mu}\right)
$$

2.8. High-Speed Centrifugation. Harvested virus sample was diluted using phosphate buffer saline (PBS) into three different concentrations: $25 \%, 50 \%$, and $100 \%(\mathrm{v} / \mathrm{v})$. About $1.8 \mathrm{~g}$ of Polyethylene Glycol 600 (PEG) was added into $40 \mathrm{~mL}$ of each virus sample and stirred in a sealed centrifuge tube at $4^{\circ} \mathrm{C}$ for 4 hours. After 4 hours, samples were centrifuged at $4^{\circ} \mathrm{C}$ at designed speed and time. After that the pellet for each sample was resuspended in $0.4 \mathrm{~mL}$ PBS and transferred into a centrifuge tube. The suspended pellet was later sonicated for 30 seconds until aggregates were disrupted. The debris was then spinned out at $14000 \mathrm{rpm}$ for 10 minutes. HA test was performed to determine the final titer.

2.9. Haemagglutination Assay (HA) Test. The haemagglutination assay (HA) method described by Grimes [19] was used. Using a 96-well V-shaped microtiter plate, $50 \mu \mathrm{l}$ PBS was added from wells $2 \mathrm{~A}-12 \mathrm{~A}$. One hundred microlitres of virus sample was added to well $1 \mathrm{~A}$ to which $50 \mu \mathrm{l}$ of it was serially diluted up to well $11 \mathrm{~A}$. Fifty microlitres of $1 \%$ red blood cell (RBC) was added to all wells. Agglutination of RBC was observed in wells containing the virus while clumping of $\mathrm{RBC}$ was seen in wells containing no virus. Dilution of the last well showing agglutination gave the titer of the virus sample. Haemagglutination units were multiplied by 20 and, therefore, expressed per $\mathrm{mL}$ as $\mathrm{HAU} / \mathrm{mL}$.

2.10. $T C I D_{50}$ Assay. Fifty percent tissue culture infectious dose $\left(\mathrm{TCID}_{50}\right)$ assay was carried out in 96-well flat shaped microtiter plates. Plates were seeded with Vero cells such that confluence was reached in 2-3 days. Vero cells were grown in DMEM media containing $10 \% \mathrm{FBS}$ and grown at $37^{\circ} \mathrm{C}$, $5 \% \mathrm{CO}_{2}$. Appropriate dilutions of each virus were prepared in DMEM medium and $100 \mu \mathrm{l}$ of each dilution was added to each well. Plates were incubated at $37^{\circ} \mathrm{C}$ for $30-60 \mathrm{~min}$ before $100 \mu \mathrm{L}$ of DMEM was added to each well. The plates were then incubated for 4 days until the CPE effect was appeared. The $\log \mathrm{TCID}_{50} / \mathrm{mL}$ calculation was based on the Reed and Muench [20] formula.

2.11. Taguchi's Orthogonal Design. Taguchi L4 array was used to design NDV production in bioreactor experiments. Three factors that were chosen to be manipulated in four runs of experiment are size of cell inoculums, serum concentration during virus production phase, and multiplicity of infection, MOI. The levels of the factors studied and the layout of the L4 Taguchi's orthogonal array are shown in Table 1.

2.12. Fractional Factorial Design. $3^{* *}(3-1)$ Fractional Factorial Design was used to assist high-speed centrifugation experiments. Three factors that were chosen to be manipulated in nine runs of experiment are sample concentration, speed, and time. The levels of the factors studied and the layout of the fractional factorial design are shown in Table 2.
TABLE 1: The L4 array Taguchi layout.

\begin{tabular}{lcc}
\hline & \multicolumn{2}{c}{ Level } \\
& 1 & 2 \\
\hline Cell inoculum $(A)($ cells $/ \mathrm{mL})$ & $0.5 \times 10^{5}$ & $1.0 \times 10^{5}$ \\
Serum concentration $(B)(\%)$ & 0.5 & 2 \\
MOI $(C)$ & 0.2 & 2 \\
\hline
\end{tabular}

Table 2: $3^{* *}(3-1)$ Fractional Factorial Design for High-Speed Centrifugation.

\begin{tabular}{lccc}
\hline & \multicolumn{3}{c}{ Level } \\
& -1 & 0 & 1 \\
\hline Sample conc. $(A)(\%)$ & 25 & 50 & 100 \\
Speed $(B)(\mathrm{rpm})$ & 6400 & 12800 & 19200 \\
Time $(C)(\mathrm{h})$ & 4 & 8 & 12 \\
\hline
\end{tabular}

\section{Results and Discussion}

3.1. Selecting Culture Media for Growth of Vero Cells. Four different culture media, MEM, DMEM, L-15, and RPMI 1640, have been used to culture Vero cells in T-flasks in order to determine which medium has the capability to yield the maximum cell concentration. As shown in Figure 1, culture of Vero cells in DMEM has generated the maximum cell concentration which was $1.93 \times 10^{6}$ cells $/ \mathrm{mL}$. This is followed by culture of Vero cells in Leibovitz's L-15 media which has yielded $1.5 \times 10^{6}$ cells $/ \mathrm{mL}$, MEM $\left(1.42 \times 10^{6}\right.$ cells $\left./ \mathrm{mL}\right)$, and RPMI $\left(7.55 \times 10^{5}\right.$ cells $\left./ \mathrm{mL}\right)$.

Growth of Vero cells in DMEM was in lag phase from $0 \mathrm{~h}$ until $40 \mathrm{~h}$. Starting from $40 \mathrm{~h}$, the culture entered exponential phase and reached the maximum cell concentration at $56 \mathrm{~h}$. Once reached the maximum, cell concentration dropped continuously until the end of the culture. From growth kinetic aspect, again culture of Vero cells in DMEM had achieved the best result where the specific growth rate $\mu_{x}$ and doubling time $t_{d}$ recorded were $0.052 \mathrm{~h}^{-1}$ and 13.11 hours. This is followed by L-15 with $\mu_{x}$ of $0.042 \mathrm{~h}^{-1}$ and $t_{d}$ of 16.38 hours, MEM $\left(\mu_{x}=0.041\right.$ and $\left.t_{d}=16.72 \mathrm{~h}\right)$, and RPMI ( $\mu_{x}=0.036$ and $\left.t_{d}=19.20 \mathrm{~h}\right)$. Based on these results, DMEM was selected to be used in further stages of the study because it has the best performance in terms of maximum cell concentration yielded and also growth kinetic.

DMEM has more glucose and glutamine concentration than any other medium does thereby sustaining the growth of cells for a longer period. Glucose and glutamine are the most vital nutrients in media providing carbon and nitrogen source, respectively, thus vital for cellular metabolism [21]. In addition, DMEM is also reported as able to support the growth of cells to much higher densities compared to many other culture media because the concentrations of certain essential amino acids and vitamins are several fold greater in DMEM than in the other media.

3.2. Selecting Microcarrier for Growth of Vero Cells. A twolitre bench-top bioreactor was used to culture Vero cells on four different types of microcarrier to determine which type 


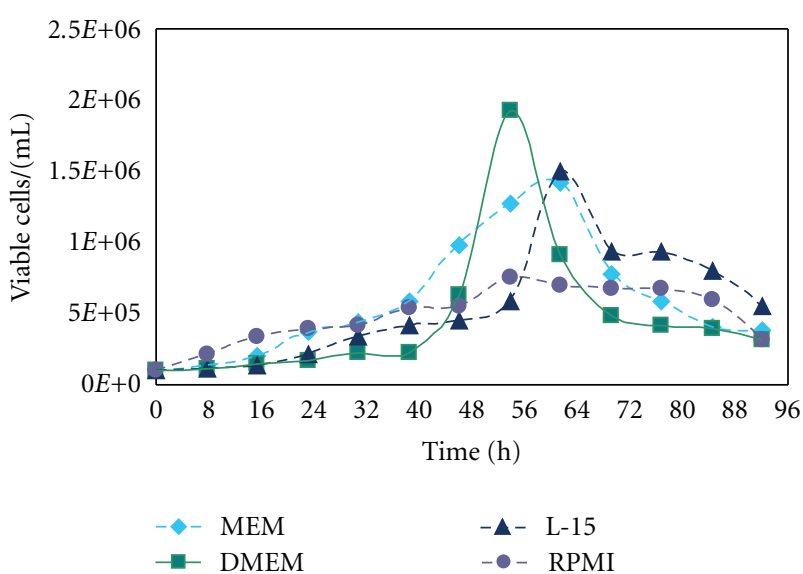

Figure 1: Comparison of Vero cell growth in four different culture media. All media were supplemented with $10 \%$ fetal bovine serum (FBS).

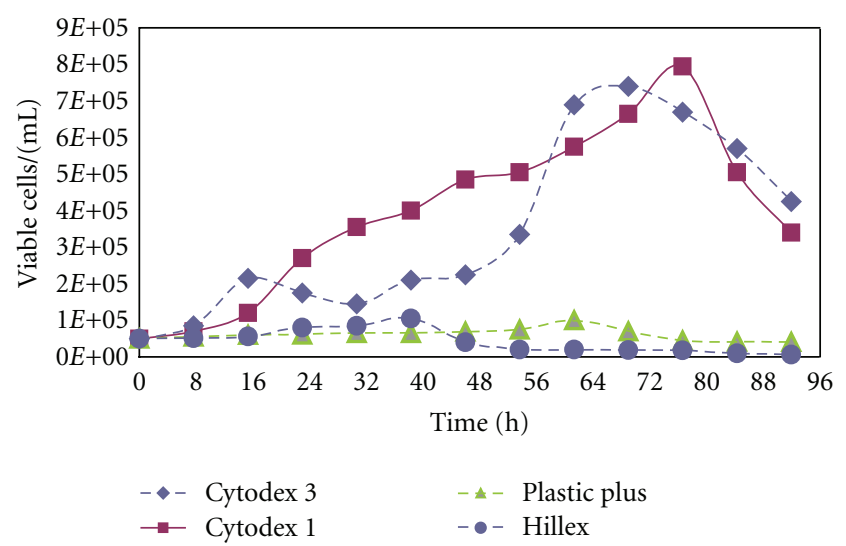

Figure 2: Comparison of Vero cell growth on different types of microcarrier in a $2 \mathrm{~L}$ stirred tank bioreactor.

of microcarrier can best support the growth of Vero cells in a nonstatic culture. Four types of commercial microcarriers that were selected for this purpose were Cytodex 1, Cytodex 3, Hillex, and Plastic Plus (PP). Figure 2 shows the growth profile of Vero cells on all types of microcarrier. From the figure it can be seen that the growth of Vero cells on Cytodex 1 microcarrier yielded the maximum cell concentration which was $7.95 \times 10^{5}$ cells $/ \mathrm{mL}$. This is followed by culture of Vero cells on Cytodex 3 which has yielded $7.40 \times 10^{5}$ cells $/ \mathrm{mL}$, Hillex $\left(1.05 \times 10^{5}\right.$ cells $\left./ \mathrm{mL}\right)$, and Plastic Plus (PP) $(1.00 \times$ $10^{5}$ cells $/ \mathrm{mL}$ ). Cell attachment on each type of microcarrier could be clearly observed by microscopic examination as shown in Figures 3(a)-3(d).

In terms of growth kinetic aspect, the best result was shown by Vero cell culture on Cytodex 3 microcarriers which had the specific growth rate $\mu_{x}$ and doubling time $t_{d}$ of $0.052 \mathrm{~h}^{-1}$ and 13.11 hours. This is followed by Cytodex 1 with $\mu_{x}$ of $0.035 \mathrm{~h}^{-1}$ and $t_{d}$ of 20.04 hours, Hillex $\left(\mu_{x}=\right.$ 0.018 and $\left.t_{d}=37.36 \mathrm{~h}\right)$, and Plastic Plus (PP) $\left(\mu_{x}=0.011\right.$ and $t_{d}=64 \mathrm{~h}$ ). Although Cytodex 3 microcarriers had the highest specific growth rate and the lowest doubling

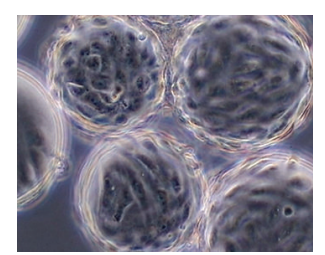

(a)

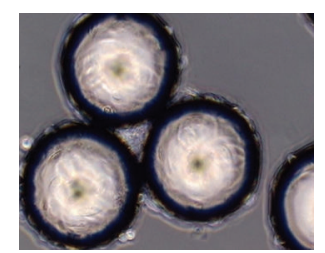

(c)

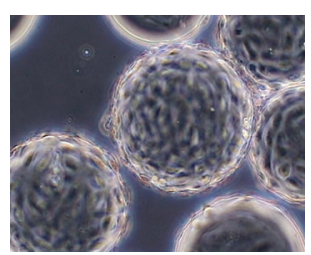

(b)

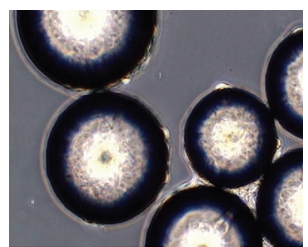

(d)
FIGURE 3: Cell attachment of Vero cells on four different microcarriers viewed under inverted light microscope at magnification of 20x: (a) Cytodex 1; (b) Cytodex 3; (c) Hillex; (d) Plastic Plus (PP).

time, the differences compared to Cytodex 1 microcarriers were not significant as compared to the other two types of microcarriers. Therefore Cytodex 1 can be regarded as the optimum for supporting cell growth and was selected to be used in later stages of the study.

Both Cytodex 1 and Cytodex 3 microcarriers produced by Amersham Biosciences are made from dextran while Hillex and Plastic Plus (PP) microcarriers which are produced by SoloHill Inc. are made from polystyrene material. Dextran is a degradable material that allows cells to be harvested easier compared to polystyrene which is a nondegradable material [22]. This fact may partially explain for lower cell concentration obtained when using Hillex and Plastic Plus (PP) polystyrene microcarriers compared to both Cytodex microcarriers.

Another observation was the concentration of microcarrier used. In this study, Cytodex 1 and 3 microcarriers were used at a concentration of $3 \mathrm{~g} / \mathrm{l}$ while Hillex and Plastic Plus (PP) microcarriers were used at $14 \mathrm{~g} / \mathrm{l}$ and $20 \mathrm{~g} / \mathrm{l}$, respectively, as recommended by the manufacturers. Mendonça and Pereira [23] and Julien [24] reported that high concentrations of microcarriers in bioreactor culture reduced the ability of cells to attach due to increased shear stress emanating from collisions between microcarriers.

3.3. Vero Cell Culture in Bioreactor for NDV Production. To optimize production of NDV in the bioreactor, the effects of the following three factors have been investigated: cell inoculum size (factor $A$ ), serum concentration during virus replication phase (factor $B$ ), and multiplicity of infection, MOI (factor $C$ ). These factors were manipulated in four runs of experiment that was designed using Taguchi L4 model.

Figures 4(a)-4(d) show the growth profile of Vero cells on Cytodex 1 microcarriers and the kinetic of NDV replication. In all four runs, virus was infected to the culture at $72 \mathrm{~h}$. From the figure, it can be observed that similar behaviour was exhibited in all four runs where viable cell concentration dropped sharply after infection and continues to decrease 
TABLE 3: NDV Production result (HA and TCID50).

\begin{tabular}{lccccc}
\hline Run & Cell inoculums $($ cells/mL) $(A)$ & Serum conc. $(\%)(B)$ & MOI $(C)$ & Max. HA titer $(\mathrm{HAU} / \mathrm{mL})$ & Max. infectivity titer $\left(\mathrm{tcid}_{50} / \mathrm{mL}\right)$ \\
\hline 1 & $1.0 \times 10^{5}$ & 0.5 & 2 & 10240 & $4.79 \times 10^{7}$ \\
2 & $0.5 \times 10^{5}$ & 2 & 2 & 10240 & $4.67 \times 10^{7}$ \\
3 & $1.0 \times 10^{5}$ & 2 & 0.2 & 1280 & $3.22 \times 10^{7}$ \\
4 & $0.5 \times 10^{5}$ & 0.5 & 0.2 & 640 & $3.08 \times 10^{7}$ \\
\hline
\end{tabular}

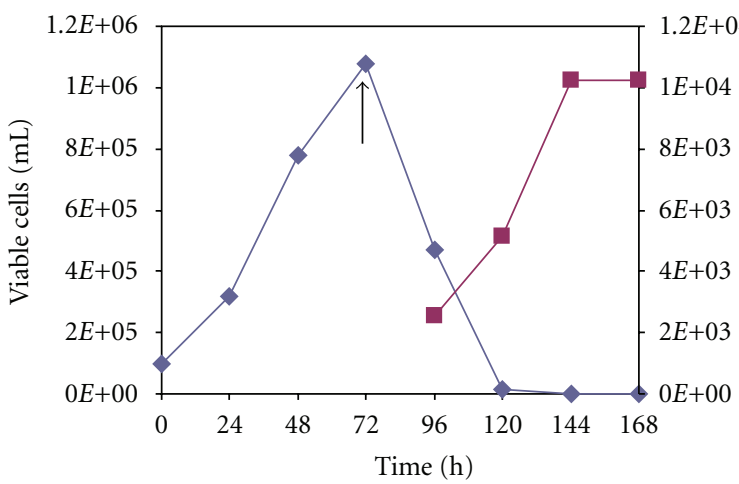

(a)

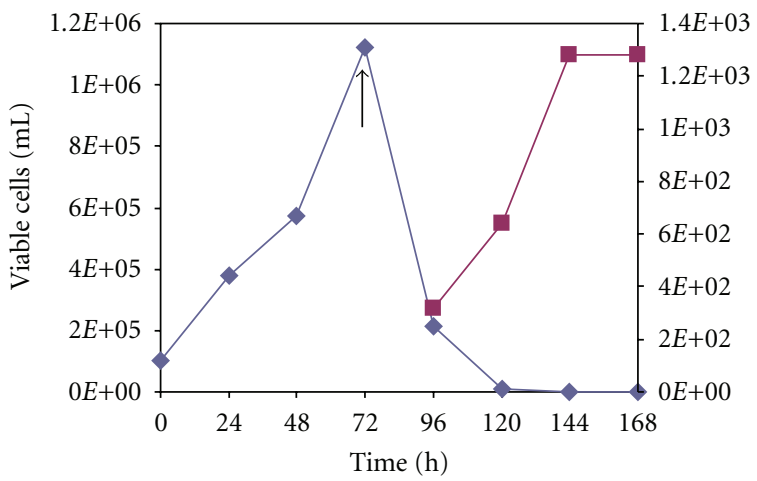

(c)

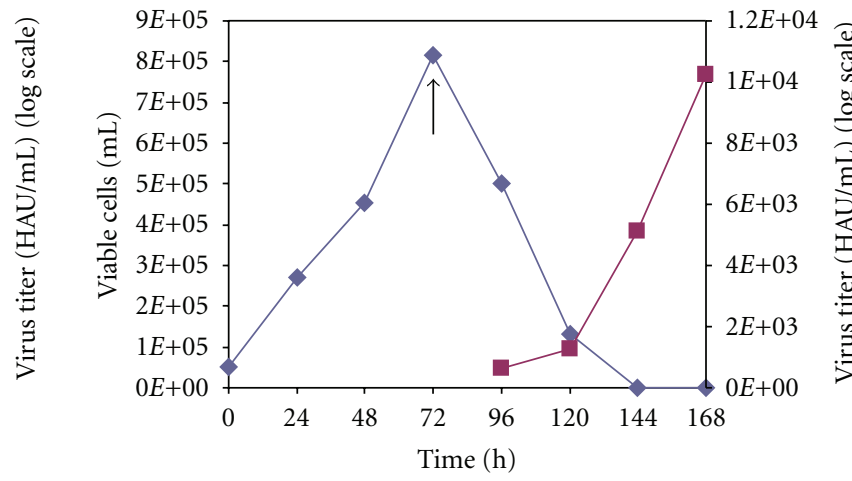

(b)

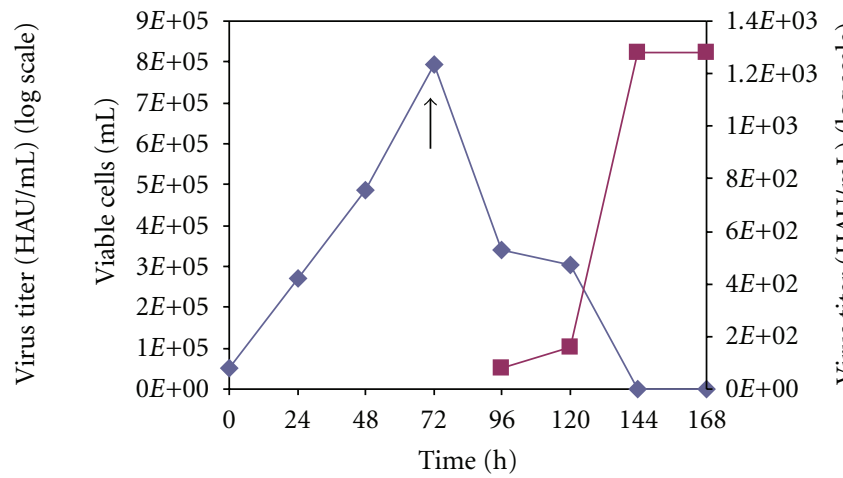

(d)

Figure 4: Growth of Vero cells on Cytodex 1 microcarrier and production of NDV: (a) cell inoculums: $1.0 \times 10^{5}$ cells $/ \mathrm{mL}$, serum concentration: $0.5 \%$, MOI: 2.0; (b) cell inoculums: $0.5 \times 10^{5}$ cells/mL, serum concentration: $2.0 \%$, MOI: 2.0 ; (c) cell inoculums: $1.0 \times$ $10^{5}$ cells $/ \mathrm{mL}$, serum concentration: $2.0 \%$, MOI: 0.2 ; (d) cell inoculums: $0.5 \times 10^{5}$ cells $/ \mathrm{mL}$, serum concentration: $0.5 \%$, MOI: 0.2 . ( $\left.\uparrow\right)$ indicates cell infection.

until the end of the culture period. Figure $5(\mathrm{a})-5(\mathrm{~d})$ shows the microscopic examination of Vero's cell growth before and after NDV infection in 2-litre stirred tank bioreactor.

Table 3 shows the maximum HA titer and maximum infectivity titer obtained for each run conducted according to the L4 Taguchi array. The lowest virus yields were reached during Run 4 . In these conditions, maximum HA titer achieved was $640 \mathrm{HAU} / \mathrm{mL}$. On the other hand, the maximum HA titer was achieved during Run 1 and Run 2 and was equal to $10240 \mathrm{HAU} / \mathrm{mL}$. Run 1 also achieved the maximum infectivity titer which was $4.79 \times 10^{7} \mathrm{tcid}_{50} / \mathrm{mL}$.

The calculation of the variance for each factor studied shows that the lowest value was obtained by factor $B$ (serum concentration during virus replication phase). This indicates that this factor did not have a significant effect on the virus titer. Thus it was neglected and its effect was considered as residual error $(R)$. Analysis of variance and ANOVA table are presented in Table 4. As shown in the table, MOI was the most significant factor in yielding NDV as it has the lowest $P$ value and less than .05 . The analysis also suggests that yield of NDV can be increased when cell inoculum and MOI are increased. For predicting the optimal values of NDV produced, a linear model was fitted to the experimental results for the NDV yield by the Design Expert software. The model developed is as follows:

$$
Y\left(\text { Virus titer, } \frac{\mathrm{HAU}}{\mathrm{mL}}\right)=-551.1+0.0064 A+5155.6 C \text {, }
$$

where the NDV production as yield $(Y)$ is a function of cell inoculum $(A)$ and multiplicity of infection, MOI $(C)$.

At the model level, multiple correlation coefficient $R$ and the determination coefficient $R^{2}$ measure for the estimation of the regression equation. The correlation between 
TABle 4: Analysis of variance (ANOVA) for Taguchi L4 model.

\begin{tabular}{lccc}
\hline Source & Sum of squares & $F$ value & $P$ value \\
\hline Model & $8.622 \times 10^{7}$ & 421 & .0344 \\
Cell inoculum, $A$ & $1.024 \times 10^{5}$ & 1 & .5000 \\
MOI, $C$ & $8.612 \times 10^{7}$ & 841 & .0219 \\
\hline
\end{tabular}

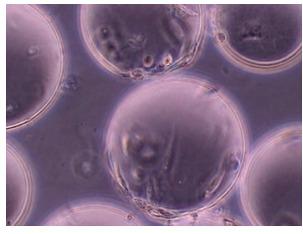

(a)

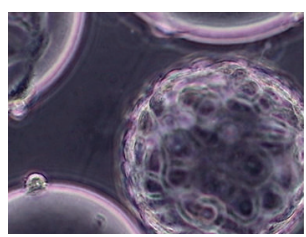

(c)

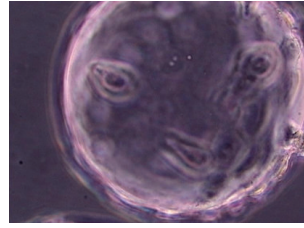

(b)

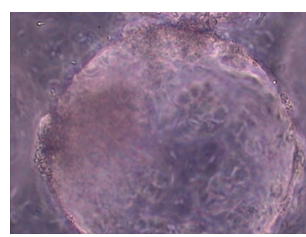

(d)
FIgURE 5: Monitoring of Cytodex 1 microcarriers during cell growth and NDV production phases of Vero cells grown in a $2 \mathrm{~L}$ bioreactor. Cells were observed with an inverted light microscope without staining: (a) day 0 , (b) day 2 , (c) day 3 , and (d) 2 day post infection.

the experimental and predicted values is better when the value of $R$ is closer to 1 . In this experiment, the values of $R$ and $R^{2}$ were 0.999 and 0.998 , respectively, for the NDV production. These indicates high degree of correlation between the experimental and the predicted values. The value of $R^{2}$ indicates that $99.8 \%$ of the factors size of cell inoculum and multipilicity of infection contribute very positively to the response. The value of $R^{2}$ is also a measure of fit of the model and it can be mentioned that only about $0.2 \%$ of the total variations were not explained by NDV yield. The value of the adjusted determination of coefficient was also very high $(99.64 \%)$ which indicates a high significance of the model.

3.4. High-Speed Centrifugation. Harvested virus samples were purified using high-speed centrifugation method. To optimize the purification, the effects of the following three factors have been investigated: sample concentration (factor $A$ ), centrifugation speed (factor $B$ ), and centrifugation time (factor $C$ ). These factors were manipulated in nine runs of experiment that was designed using $3^{* *(3-1)}$ Fractional Factorial design.

Table 5 shows the result of all nine runs of experiment. Among all runs, the maximum virus titer was achieved during Run 6 where the maximum virus titer produced was $5120 \mathrm{HAU} / \mathrm{mL}$. The results also reveal that centrifugation speed of $6400 \mathrm{rpm}$ always yielded the lowest virus titer. This suggests that this speed is not sufficient for the virus to settle down.

From Table 6, it was observed that the most significant factor is the square term of sample concentration $\left(A^{2}\right)$ which
TABLE 5: Result for high-speed centrifugation.

\begin{tabular}{lcccc}
\hline Run & $\begin{array}{c}\text { Sample } \\
\text { conc. }(\%)\end{array}$ & Speed (rpm) & Time (h) & $\begin{array}{c}\text { Virus titer } \\
(\mathrm{HAU} / \mathrm{mL})\end{array}$ \\
\hline 1 & 25 & 12800 & 12 & 2560 \\
2 & 25 & 19200 & 8 & 1280 \\
3 & 25 & 6400 & 4 & 160 \\
4 & 50 & 6400 & 12 & 1280 \\
5 & 50 & 19200 & 4 & 2560 \\
6 & 50 & 12800 & 8 & 5120 \\
7 & 100 & 19200 & 12 & 640 \\
8 & 100 & 12800 & 4 & 320 \\
9 & 100 & 6400 & 8 & 160 \\
\hline
\end{tabular}

TABLe 6: Analysis of variance (ANOVA) for $3^{* *}$ (3-1) Fractional Factorial model.

\begin{tabular}{lccc}
\hline Source & Sum of squares & $F$ value & $P$ value \\
\hline Model & 19421866 & 3.78072977 & .039909 \\
Sample conc., $A$ & 1382400 & 1.614618 & .331650 \\
Speed, $B$ & 1382400 & 1.614618 & .331650 \\
Time, $C$ & 345600 & 0.403654 & .590203 \\
$A^{2}$ & 7509943 & 8.771476 & .097601 \\
$B^{2}$ & 5467022 & 6.385382 & .127366 \\
$C^{2}$ & 1742222 & 2.034884 & .289843 \\
\hline
\end{tabular}

has the least $P$ value of .097601 . For predicting the optimal values of NDV titer produced, a second-order polynomial model was fitted to the experimental results by Statistica software. The model developed is as follows:

$$
\begin{aligned}
Y\left(\text { Virus titer, } \frac{\mathrm{HAU}}{\mathrm{mL}}\right)= & -12355.6+184.5(A)-1.6\left(A^{2}\right) \\
& +1.1(B)-0.0\left(B^{2}\right)+993.3(C) \\
& -58.3\left(C^{2}\right)
\end{aligned}
$$

where the NDV titer produced as yield $(Y)$ is a function of sample concentration $(A)$, centrifugation speed $(B)$, and centrifugation time $(C)$.

Correlation coefficient $R$ and the determination coefficient $R^{2}$ obtained in this experiment are 0.9586 and 0.9189 , respectively. Value of $R$ that is close to 1 indicates that the correlation between the experimental values of this experiment with the predicted values is high. The software also deduced that the maximum NDV titer can be produced when the sample concentration is $58.45 \%$, centrifugation speed is $13729.03 \mathrm{rpm}$, and centrifugation time is 8.51 hours.

\section{Conclusion}

In this study, DMEM was found to be the most suitable culture medium for growing Vero cells when compared to Leibovitz's L-15, RPMI 1640, and MEM. Also among several types of microcarrier that have been tested, Cytodex 1 
stood out as the best substrate for cells to adhere and grow in nonstatic culture. From analysis using statistical software like Design Expert and Statistica, it has been found that NDV production in $2 \mathrm{~L}$ stirred tank bioreactor can be improved when size of cell inoculums and MOI is increased. Also it has been analyzed that the optimum conditions to purify NDV using high-speed centrifugation are sample concentration of $58.45 \%$, centrifugation speed of $13729.03 \mathrm{rpm}$, and centrifugation time of 8.51 hours.

\section{Acknowledgments}

This work was funded by the Ministry of Science, Technology and Innovation of Malaysia under Grant ABI-A21. The authors wish to thank Mr. Kamaruddin from Universiti Putra Malaysia for providing the virus sample.

\section{References}

[1] D. F. Adene, "Country report on the management and health problems of rural poultry stock in Nigeria," in Proceedings of the Centre for Tropical Agriculture (CTA) Seminar on Small Holder Rural Poultry Production, pp. 175-182, Thessaloniki, Greece, October 1990.

[2] Z. Huang, S. Krishnamurthy, A. Panda, and S. K. Samal, "Newcastle disease virus V protein is associated with viral pathogenesis and functions as an alpha interferon antagonist," Journal of Virology, vol. 77, no. 16, pp. 8676-8685, 2003.

[3] D. J. Alexander, "Newcastle disease and other avian paramyxoviridae infections," in Diseases of Poultry, Y. M. Saif, H. J. Barnes, J. R. Glisson, A. M. Fadly, L. R. McDougald, and D. E. Swayne, Eds., pp. 63-87, Iowa State University Press, 11th edition, 2003.

[4] O. De Leeuw and B. Peeters, "Complete nucleotide sequence of Newcastle disease virus: evidence for the existence of a new genus within the subfamily Paramyxovirinae," Journal of General Virology, vol. 80, no. 1, pp. 131-136, 1999.

[5] B. S. Seal, D. J. King, and H. S. Sellers, "The avian response to Newcastle disease virus," Developmental and Comparative Immunology, vol. 24, no. 2-3, pp. 257-268, 2000.

[6] OIE, Office International des Epizooties/World Organization for animal Health, "Newcastle disease," in Manual of Standards for Diagnostic Tests and Vaccines, 2000, http://www.oie.int/eng/normes/mmanual/A_00036.htm.

[7] D. J. Alexander, "Paramyxoviridae: infection and immunity," in Encyclopedia of Immunology, I. M. Roit and P. J. Wes, Eds., vol. 3, pp. 1203-1205, London Academic Pres, London, UK, 1992.

[8] G. E. Gallili and D. Ben-Nathan, "Newcastle disease vaccines," Biotechnology Advances, vol. 16, no. 2, pp. 343-366, 1998.

[9] J. M. DiNapoli, L. Yang, A. Suguitan Jr., et al., "Immunization of primates with a newcastle disease virus-vectored vaccine via the respiratory tract induces a high titer of serum neutralizing antibodies against highly pathogenic avian influenza virus," Journal of Virology, vol. 81, no. 21, pp. 11560-11568, 2007.

[10] P. V. Ravindra, A. K. Tiwari, B. Ratta, et al., "Induction of apoptosis in Vero cells by Newcastle disease virus requires viral replication, de-novo protein synthesis and caspase activation," Virus Research, vol. 133, no. 2, pp. 285-290, 2008.

[11] A. L. Van Wezel, "Growth of cell-strains and primary cells on micro-carriers in homogeneous culture," Nature, vol. 216, no. 5110, pp. 64-65, 1967.
[12] A. L. van Wezel, C. A. van der Velden-de Groot, and J. A. van Herwaarden, "The production of inactivated poliovaccine on serially cultivated kidney cells from captive-bred monkeys," Developments in Biological Standardization, vol. 46, pp. 151$158,1980$.

[13] B. Meignier, H. Mougeot, and H. Favre, "Foot and mouth disease virus production on microcarrier-grown cells," Developments in Biological Standardization, vol. 46, pp. 249-256, 1980.

[14] K. Trabelsi, S. Rourou, H. Loukil, S. Majoul, and H. Kallel, "Comparison of various culture modes for the production of rabies virus by Vero cells grown on microcarriers in a 2-1 bioreactor," Enzyme and Microbial Technology, vol. 36, no. 4, pp. 514-519, 2005.

[15] P. van Hemert, D. G. Kilburn, and A. L. van Wezel, "Homogeneous cultivation of animal cells for the production of virus and virus products," Biotechnology and Bioengineering, vol. 11, no. 5, pp. 875-885, 1969.

[16] R. I. Freshney, Culture of Animal Cells: A Manual of Basic Technique, John Wiley \& Sons, Glasgow, UK, 4th edition, 2000.

[17] Pharmacia: Microcarrier Cell Culture and Method, Pharmacia LKB Technology, Uppsala, Sweden, 1991.

[18] W. Scheirer and O. W. Merten, "Instrumentation of animal cell culture reactors," in Animal Cell Bioreactors, C. S. Ho and D. I. C. Wang, Eds., pp. 405-443, Butterworth-Heinemann, Boston, Mass, USA, 1991.

[19] S. E. Grimes, A Basic Laboratory Manual for the Small Scale Production and Testing of I-2 Newcastle Disease Vaccine, Food and Agricultural Organization (FAO), Animal Production and Health Commission for Asia and the Pacific (APHCA), 2002.

[20] L. J. Reed and H. Muench, "A simple method for estimating $50 \%$ endpoints," American Journal of Hygiene, vol. 27, pp. 493497, 1932.

[21] ECACC, European Collection of Cell Cultures, Fundamental Techniques in Cell Culture: A Laboratory Handbook, Sigma Aldrich, 2001.

[22] B. L. Seal, T. C. Otero, and A. Panitch, "Polymeric biomaterials for tissue and organ regeneration," Materials Science and Engineering, vol. 34, no. 4-5, pp. 147-230, 2001.

[23] R. Z. Mendonça and C. A. Pereira, "Cell metabolism and medium perfusion in VERO cell cultures on microcarriers in a bioreactor," Bioprocess Engineering, vol. 18, no. 3, pp. 213-218, 1998.

[24] J. Julien, "Hydrodynamics, mass transfer and rheological studies of Gibberellic acid production in a stirred tank bioreactor," World Journal of Microbial Biotechnology, vol. 23, pp. 615-623, 2003. 

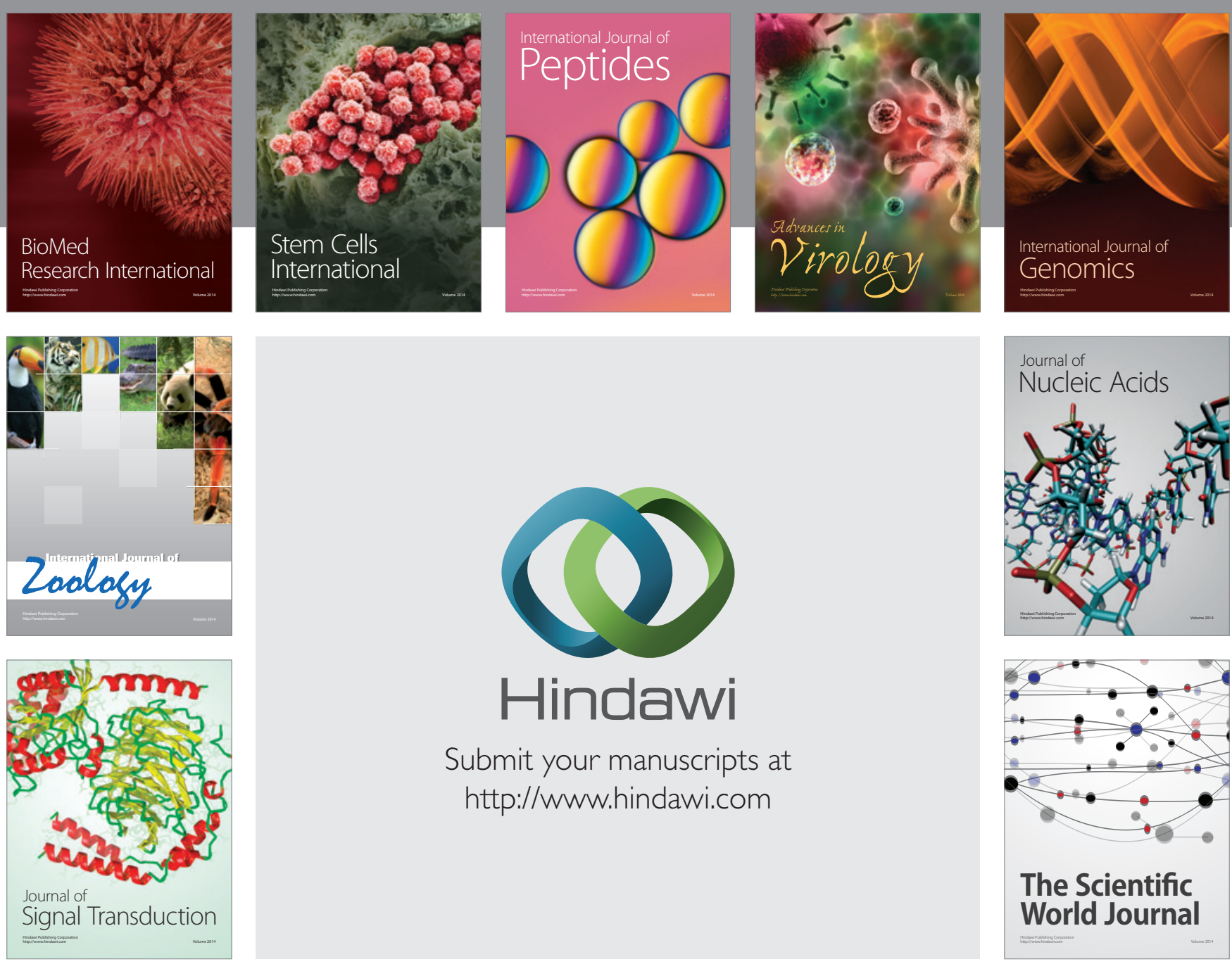

Submit your manuscripts at

http://www.hindawi.com
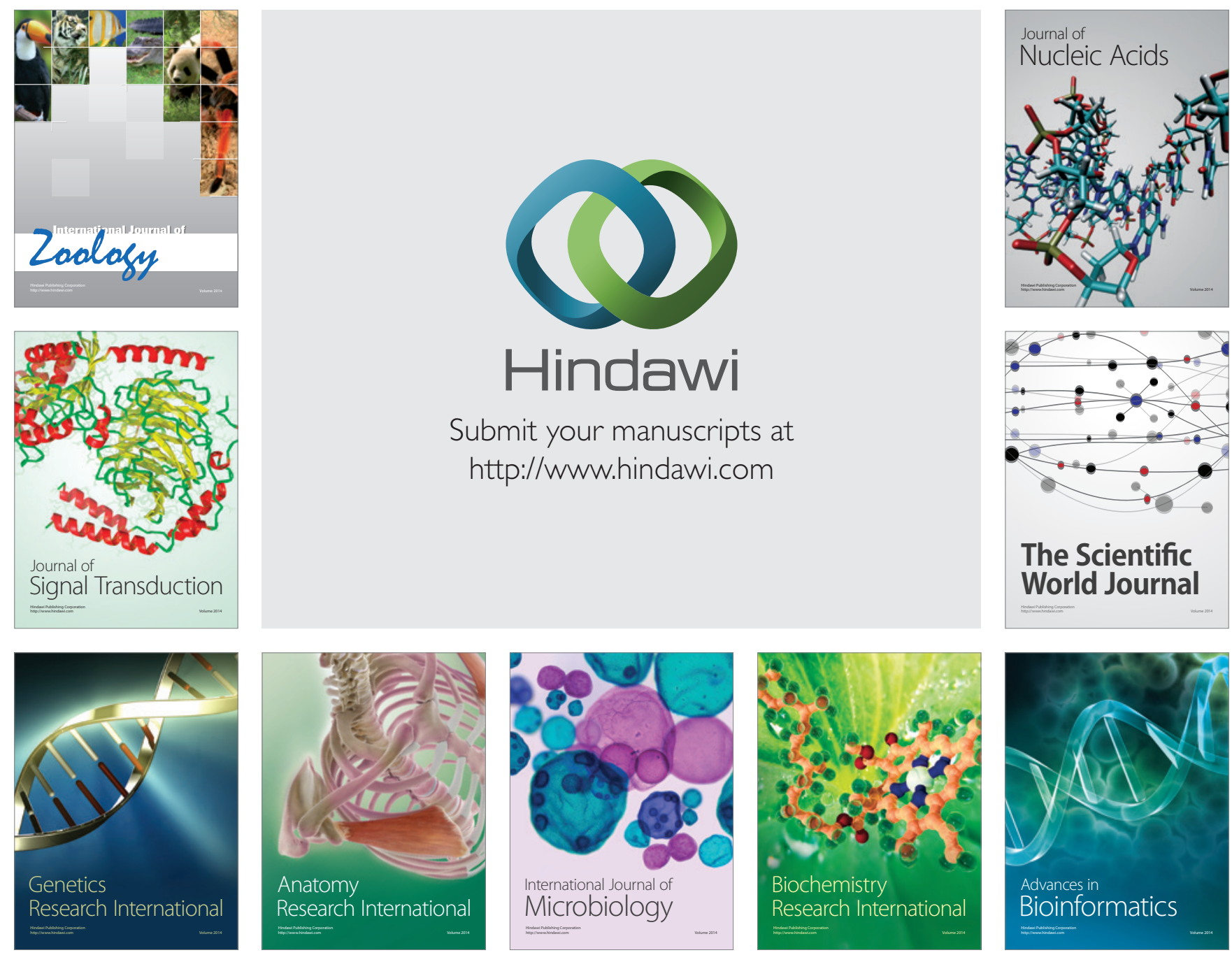

The Scientific World Journal
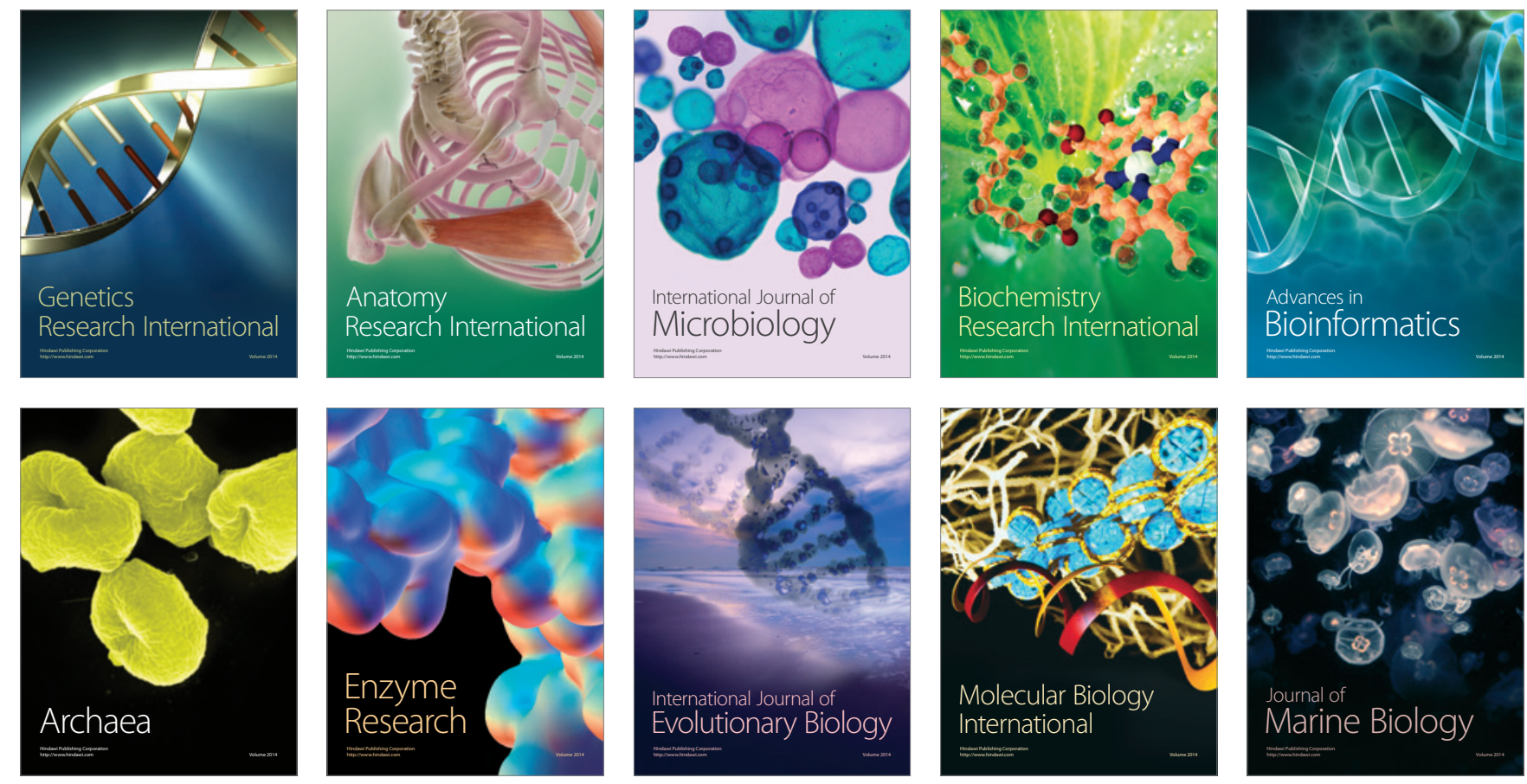